\title{
Effects of iron-ore particles on propagule release, growth and photosynthetic performance of Sargassum vulgare C. Agardh (Phaeophyta, Fucales)
}

\author{
CRISTINA A.G. NASSAR ${ }^{1,3}$, HELENA P. LAVRADO² and YOCIE YONESHIGUE-VALENTIN ${ }^{1}$
}

(received: October 10, 2001; accepted: July 31, 2002)

\begin{abstract}
Effects of iron-ore particles on propagule release, growth and photosynthetic performance of Sargassum vulgare C. Agardh (Phaeophyta, Fucales)). The effect of iron-ore particles on the propagule release and growth of Sargassum vulgare C. Agardh was tested under treatments with different concentrations of iron-ore particles: $0.1,1.0,10.0$ g.L $\mathrm{L}^{-1}$ and a

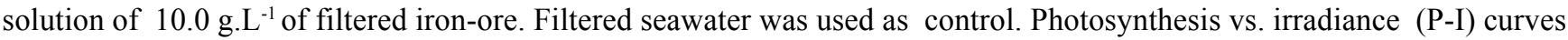
were calculated for $S$. vulgare in the presence of iron-ore and in seawater. There was no significant difference in the number of propagules released by the receptacles or in the percentage of zygote formation among the treatments. The released propagules acted like aggregation centers for the particles, those more heavily coated with iron (10.0 g.. $\left.\mathrm{L}^{-1}\right)$ exhibiting the highest sinking velocity $\left(32.6 \pm 9.8 \mathrm{~mm} \cdot \mathrm{s}^{-1}\right)$. No difference in the percentage of embryo survival was detected during the first week in culture. After four weeks the embryos grew in all treatments. Maximum frond development $(5.3 \pm 0.8 \mathrm{~mm})$ was observed in treatment of seawater enriched with Provasoli's medium (PES) while initial filoids did not develop in three treatments without PES and with iron-ore $\left(0.1\right.$ g.L. $\mathrm{L}^{-1}, 1.0 \mathrm{~g} . \mathrm{L}^{-1}$ and $\left.10.0 \mathrm{~g} . \mathrm{L}^{-1}\right)$. The values for $\mathrm{P}_{\max }$, alpha and respiration showed no significant differences between the P-I curves. The calculated value for $\mathrm{I}_{\mathrm{K}}$ was $106.26 \mu \mathrm{mol} \cdot \mathrm{m}^{-2} \cdot \mathrm{s}^{-1}$ to the control curve and $981.49 \mu \mathrm{mol}^{-2} \mathrm{~m}^{-1} \mathrm{~s}^{-1}$ to the iron-ore curve. The results indicate that the iron-ore particles in high concentration reduce the growth of $S$. vulgare as they recovered the embryos, juveniles and young plants. In contrast, the presence of the particles did not affect the release of gametes, percentage of zygote formation or the percentage of embryo survival.
\end{abstract}

RESUMO - (Efeitos de partículas de minério de ferro sobre a liberação de propágulos, crescimento e desempenho fotossintético de Sargassum vulgare C. Agardh (Phaeophyta, Fucales)). Os efeitos das partículas de minério de ferro na liberação e desenvolvimento de propágulos de Sargasssum vulgare C. Agardh foram testados em diferentes concentrações de minério de ferro: $0,1,1,0,10,0$ g.L $\mathrm{L}^{-1}$ e na solução de 10,0 g.L $\mathrm{L}^{-1}$ de filtrado de minério. Água do mar filtrada foi utilizada como controle. Curvas de fotossíntese vs. irradiância (P-I) foram calculadas para S. vulgare na presença de minério de ferro e em água do mar. Não houve diferença significativa no número de propágulos liberados e nem na percentagem de zigotos formados entre os tratamentos. Os propágulos liberados atuam como centro de agregação para as partículas, onde as mais densamente recobertas por ferro $\left(10,0 \mathrm{~g} . \mathrm{L}^{-1}\right)$ apresentaram a mais alta velocidade de decantação $\left(32,6 \pm 9,8 \mathrm{~mm} . \mathrm{s}^{-1}\right)$. Nenhuma diferença na percentagem de sobrevivência de embriões foi observada durante a primeira semana de cultivo. Após quatro semanas de experimento, os embriões cresceram em todos os tratamentos. O desenvolvimento máximo das frondes $(5,3 \pm 0,8 \mathrm{~mm})$ ocorreu no tratamento com água do mar enriquecida com o meio de Provasoli (PES). Em três tratamentos sem PES e com minério de ferro, o inicial dos filóides não se desenvolveram $\left(0,1,1,0\right.$ e 10,0 g. $\left.\mathrm{L}^{-1}\right)$. Os valores de $\mathrm{P}_{\max }$, alpha e respiração não apresentaram diferença significativa entre as curvas de P-I. Os valores calculados para $I_{K}$ foram $106,26 \mu \mathrm{mol} . \mathrm{m}^{-2} \mathrm{~s}^{-1}$ para curva controle e $981,49 \mu \mathrm{mol} . \mathrm{m}^{-2} . \mathrm{s}^{-1}$ para a curva com minério de ferro. Os resultados indicam que as partículas de minério de ferro em alta concentração reduzem o crescimento de $S$. vulgare uma vez que elas recobrem os embriões, juvenis e plantas jovens. Já a presença das partículas não afetou a liberação de gametas, a percentagem de formação de zigotos ou a sobrevivência de embriões.

Key words - Growth, iron-ore, macroalgae, net photosynthesis, Sargassum vulgare

\section{Introduction}

The iron-ore is the raw material for an important economic sector - the steel industry. Brazil is one of

\footnotetext{
1. Universidade Federal do Rio de Janeiro, CCS, Instituto de Biologia, Departamento de Botânica, 21944-970 Ilha do Fundão, Rio de Janeiro, Brazil.

2. Universidade Federal do Rio de Janeiro, CCS, Instituto de Biologia, Departamento de Biologia Marinha, 21944-970 Ilha do Fundão, Rio de Janeiro, Brazil.

3._Corresponding author: nassarc@biologia.ufrj.br
}

the greatest producers of this mineral, which is exported overseas by shipping. The iron-ore can reach coastal waters through accidental spillage during the process of ship loading and unloading or during transportation. A single event can result in tons of this particulate matter entering the environment in a very short period of time. In the Espírito Santo Bay (Espírito Santo Brazil), both the seabed and seashore macroalgal communities are covered with iron-ore (Mitchell et al. 1990). In this bay, close to an abandoned discharge from an iron-ore processing plant, the brown alga Sargassum 
vulgare C. Agardh has been absent for over a decade (C.A.G. Nassar, unpublished data).

Sargassum is often the dominant component of shallow sublittoral communities from tropical and subtropical waters (Paula \& Oliveira Filho 1980, Hanisak \& Samuel 1987, Paula 1988). S. vulgare is a very abundant species in the Southeastern coast of Brazil, reaching impressive length and biomass (Paula 1988, Széchy \& Paula 2000). The morphological complexity of the fronds allows the existence of a rich epibenthic community associated to Sargassum (Mansilla \& Pereira 1998, Széchy \& Paula 2000). The early phases of different species tend to be the most sensitive to environmental changes. Thus, anything that affects them can compromise the future of the whole population and all others species dependent on it (Hopkin \& Kain 1978, Burridge et al. 1999). Sargassum propagules (gametes, zygotes or embryos) are exceptional experimental organisms due to their environmental sensibility and to the relative easiness with which they can be obtained in large numbers (De Wreede 1978).

Some studies mention the effect of different kinds of sediment over the propagules of algal species (Burrows 1971, Devinny \& Volse 1978, Norton 1978), but none describes the effect of iron-ore particles on the development of the macroalgae. This mineral are mainly composed of $\mathrm{Fe}^{+3}$ oxides and hydroxides which, for being insoluble in seawater, are not available to the biota (Boney 1978, Sunda \& Huntsman 1995). Even though this ore is not toxic or absorbed by algae, juvenile plants and propagules can be adversely affected by it. Boney (1978) speculated that the presence of ore in the water could cut down light penetration resulting in reduced growth rates and that coating of the algal surfaces, by this particulate matter, would likely reduce the uptake of nutrients and the gaseous exchange. Results of a study about the effects of an iron-ore on the oospheres of Fucus serratus L., indicated that the latter act as aggregation centers for the metal particles, becoming less efficient in attracting the male gametes (Boney 1980).

The hypothesis tested is that the iron-ore particles are a physical barrier to the reproduction, growth and net photosynthesis of Sargassum vulgare. This study examined the effect of iron-ore particles on the release of propagules, the development of zygotes and juveniles of $S$. vulgare when exposed to different concentrations of the mineral. It was also tested the influence of iron-ore particles on net photosynthesis of $S$. vulgare under different levels of irradiance. At last, the zygote sinking velocity was estimated for different treatments.

\section{Material and methods}

Fertile plants of Sargassum vulgare C. Agardh were collected during low tide in Prainha - Arraial do Cabo (Rio de Janeiro State - Brazil) two days before the full moon. Still in the field, plants bearing receptacles were washed in local seawater and cleaned of all epiphytes and associated fauna. Plants were transported to the laboratory in an insulated recipient where fertile receptacles were again washed in filtered seawater (Millipore, $0.45 \mu \mathrm{m}$ pore size). Part of the material was observed under a compound microscope to confirm the presence of oocysts and antherozoids within the conceptacles. Slides were stained with aniline blue to help observing the male gametes (Wiseman 1976).

All experiments were conducted inside a culture room at a temperature of $20{ }^{\circ} \mathrm{C}$ and photon flux density of 90-100 $\mu \mathrm{mol} . \mathrm{m}^{-2} . \mathrm{s}^{-1}$. The light:dark cycle was 12:12 hours. Seawater salinity was 35 PSU and pH 8.2. Every two days the culture media for all the treatments was changed and 10 fronds were measured and drawn under a camera lucida. The seawater was enriched with Provasoli's solution (PES) at a concentration of $1.0 \mathrm{~mL} . \mathrm{L}^{-1}$ (Provasoli 1968). The general design of experiments with $S$. vulgare can be seen in figure 1 .

The iron-ore used in this study ("pellet feed fines") was composed of $67-68 \% \mathrm{Fe}^{+3}$ with particle mean size of $47 \mu \mathrm{m}$, supplied by "Minerações Brasileiras Reunidas".

The effect of iron-ore on propagule release and on the percentage of zygote formation - fertile receptacles were detached from the parent frond and kept in conical flasks with $100 \mathrm{~mL}$ of the different treatment media. Each treatment (with nine replicates) received $0.1 \mathrm{~g}$ of receptacles (fresh weight). Five treatments were tested. Three consisted of different concentrations of iron-ore $(0.1,1.0$ and $10.0 \mathrm{~g})$ diluted in one liter of filtered seawater. Another treatment used the filtrate (filter paper Whatman 1) of 10.0 g.L. $\mathrm{L}^{-1}$ of iron-ore solution in order to effectively eliminate the particulate but not the dissolved material in the solution. As control treatment, the receptacles were kept in a solution of filtered seawater. The flasks with receptacles were kept in a orbital shaker at a constant rotation for 1 hour, then transferred to Petri dishes filled with $50.0 \mathrm{~mL}$ of filtered seawater + PES, until propagule release.

The female gametes were released in the first and second nights of the full moon. Two days later, all propagules (female gametes and zygotes), including those adhered to the conceptacles and at the bottom of the dishes, were counted under a dissecting microscope (100 x magnification). Twenty propagules from each treatment were pipetted out of the dishes and the percentage of zygote formation estimated under a compound microscope. The zygotes were differentiated from non-fertilized oocysts by the presence of octonucleated cells or by the beginning of the process of rhizoid formation (Norton 1977, Paula 1994).

Percentage of survival of embryos - after the propagules were counted in the above experiment, 25 developing zygotes 


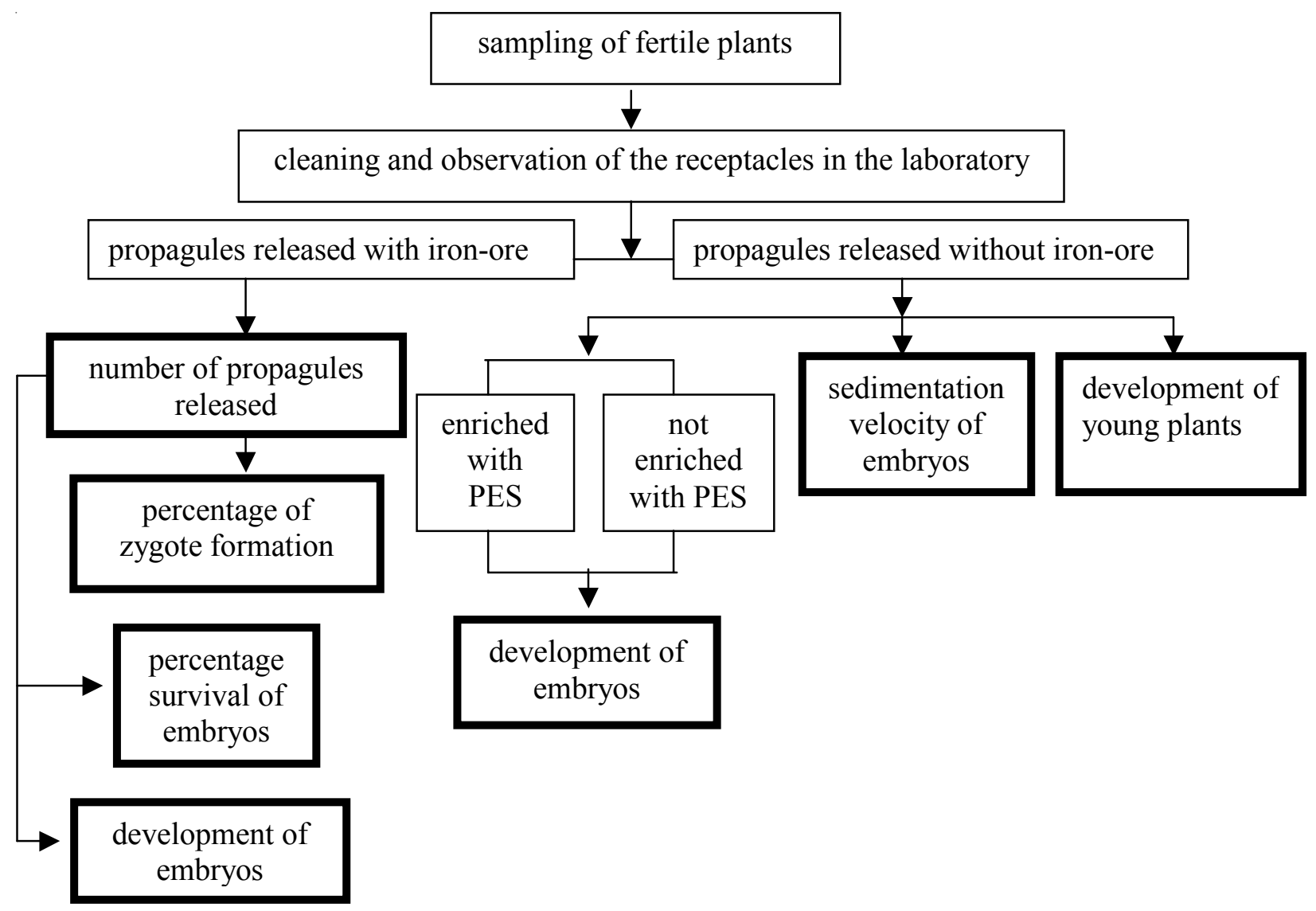

Figure 1. General design of experiments with $S$. vulgare. $\mathrm{PES}=$ Provasoli's solution.

were transferred to $250 \mathrm{~mL}$ conical flasks with $200 \mathrm{~mL}$ of medium and kept under constant aeration (nine replicates). After one week in culture, the number of surviving germlings was estimated under a dissecting microscope.

Development of the embryos formed under iron-ore exposure - Thirty embryos from the first experiment were transferred to $250 \mathrm{~mL}$ conical flasks with $200 \mathrm{~mL}$ of seawater enriched with PES and kept under constant aeration to assess their development. Germlings were measured under dissecting microscope at intervals of seven days for four weeks. Three replicates were used for each treatment.

The effect of iron-ore on embryo development - Forty-eight hours after releasing in filtered seawater, embryos from receptacles never kept in contact with iron-ore, were selected and washed twice to eliminate any biological contaminant. Fifty embryos were pipetted into $250 \mathrm{~mL}$ flasks with $200 \mathrm{~mL}$ of different treatment media (seawater, 0.1, 1.0, $10.0 \mathrm{~g} . \mathrm{L}^{-1}$ and filtrate of 10.0 g. $\mathrm{L}^{-1}$ of iron-ore solution). During this experiment the treatments were kept in two different sets, one enriched with PES and the other without PES. Three replicates were used for each treatment. Initial length was assumed as the mean length of 20 out of the 50 embryos. Influence of the iron-ore on the development of juvenile ( 30 days old) - One-month juveniles grown in seawater enriched with PES were transferred to $500 \mathrm{~mL}$ conical flasks with $400 \mathrm{~mL}$ of medium and exposed to the following treatments for one month: seawater, 10.0 g. $\mathrm{L}^{-1}$ of iron-ore filtered seawater solution and 10.0 g.L. $\mathrm{L}^{-1}$ of iron-ore solution (three replicates each). Every week the plants were blot-dried with absorbent paper and weighed in a digital scale (fresh-weight). The plants were cultivated under aeration.

Influence of the iron-ore over the sedimentation velocity of the embryos - Ten embryos never exposed to iron-ore were selected and kept in a orbital shaker (1 hour) in the following media: filtered seawater, 0.1 g.L $\mathrm{L}^{-1}, 1.0$ g.L. ${ }^{-1}, 1.0$ g.L. $\mathrm{L}^{-1}$ and $10.0 \mathrm{~g} . \mathrm{L}^{-1}$ filtered iron-ore solution. The embryos were then taken to a $500 \mathrm{~mL}$ graduated cylinder filled with seawater. The time each embryo took to sink from the surface of the cylinder water column to its bottom $(50.0 \mathrm{~cm})$ was considered their sedimentation velocity $\left(\mathrm{mm} \cdot \mathrm{s}^{-1}\right)$.

Net Photosynthesis experiment - S. vulgare was collected at Conceição de Jacareí (Rio de Janeiro) on August 2001. At the laboratory half the material was exposed to $10.0 \mathrm{~g} . \mathrm{L}^{-1}$ of iron-ore for 18 hours before the experiment. Apical fragments of lateral branches of Sargassum with $0.5 \mathrm{~g}$ (fresh weight) were incubated with filtered seawater (Millipore, $0.45 \mu \mathrm{m}$ pore size) in $250 \mathrm{~mL}$ flasks. The treatments consisted of plants incubated in seawater and plants incubated with a solution 
of seawater and 10.0 g.L. $\mathrm{L}^{-1}$ of iron-ore. Four different irradiances were obtained using nylon screening with different numbers of layers. The full natural light intensity $\left(1,445 \mu \mathrm{mol} \cdot \mathrm{m}^{-2} \cdot \mathrm{s}^{-1}\right)$ was reduced to $1,5 \%\left(22 \mu \mathrm{mol} \cdot \mathrm{m}^{-2} \cdot \mathrm{s}^{-1}\right)$, 5\% $\left(72 \mu \mathrm{mol} . \mathrm{m}^{-2} \cdot \mathrm{s}^{-1}\right), 15 \%\left(217 \mu \mathrm{mol} . \mathrm{m}^{-2} \cdot \mathrm{s}^{-1}\right)$ and $40 \%$ $\left(578 \mu \mathrm{mol} \cdot \mathrm{m}^{-2} \cdot \mathrm{s}^{-1}\right)$. Respiration values were obtained keeping the flask in a refrigerated dark box with constant temperature $\left(23{ }^{\circ} \mathrm{C}\right)$. Four replicates were used for each treatment. The net photosynthesis and the respiration were calculated by the difference between the dissolved oxygen concentration in the water, before and after the experiment. The dissolved oxygen was measured by a portable oxygen meter $\left(\mathrm{mg} . \mathrm{L}^{-1}\right)$ model Q-408P Quimis. All the light flasks were kept outdoors for one hour in a glass tank with constant flowing water and temperature $\left(24.5{ }^{\circ} \mathrm{C}\right)$. The natural light was recorded continuously during the experiment by a Li-Cor data logger model LI-1000 connected to a spherical quantum sensor model LI-1935A. The photosynthetic active radiation (PAR) was recorded at every 10 minutes from 10:00 - 14:00 h. The methodology was partially adapted from Coutinho et al. (1989).

The photosynthesis - irradiance curves fitting was performed using a nonlinear least-squares regression technique and the Hyperbolic Tangent Model of Jassby \& Platt (1976).

$$
\left.\mathrm{P}=\mathrm{P}_{\max } \text {. tanh (alpha. } \mathrm{I} / \mathrm{P}_{\max }\right)+\mathrm{R}
$$

where $\mathrm{P}_{\max }=$ maximum photosynthetic rate at saturating irradiance $\left(\mathrm{mgO}_{2} \cdot \mathrm{gdw}^{-1} \cdot \mathrm{h}^{-1}\right)$, alpha $=$ initial slope of the curve at pre-saturation irradiance $\left(\mathrm{mLO}_{2} \cdot \mathrm{gdw}^{-1} \cdot \mathrm{h}^{-1}\left(\mu \mathrm{mol} \cdot \mathrm{m}^{-2} \cdot \mathrm{s}^{-1}\right)^{-1}\right)$, $\mathrm{I}=$ irradiance $\left(\mu \mathrm{mol} \cdot \mathrm{m}^{-2} \cdot \mathrm{s}^{-1}\right), \mathrm{R}=$ rate of respiration in the dark $\left(\mathrm{mgO}_{2} \cdot \mathrm{gdw}^{-1} \cdot \mathrm{h}^{-1}\right)$ and tanh $=$ hyperbolic tangent. The light saturation parameter $\left(\mu \mathrm{mol} . \mathrm{m}^{-2} \cdot \mathrm{s}^{-1}\right)$ was estimated by $\mathrm{I}_{\mathrm{k}}=\mathrm{P}_{\max } /$ alpha.

The values ( $\mathrm{v}$ ) for $\mathrm{P}_{\max }$ and alpha of both curves were compared using the $\mathrm{t}=\left(\mathrm{v}_{1}-\mathrm{v}_{2}\right) /{\sqrt{S E_{1}{ }^{2}+S E_{2}}}^{2}$ from Coutinho $\&$ Zingmark (1987). Student's t test values similar or higher than 2.0 were significant $(\mathrm{p}<0.05)$.

The statistical significance of the differences among treatments was tested using one-way ANOVA and $a$ posteriori test (Tukey's test). All statistical analyses were performed using the Statistica ${ }^{\circledR}, 1997$ software package.

\section{Results}

The transfer of receptacles from the different treatment media to the PES-enriched media resulted in a high number of propagules released, from 411 to 748 (figure 2), with no significant difference between treatments $(F=0.64, p>0.05)$. Also in terms of the percentage of zygote formation (figure 3 ), there were no differences between the treatments, with the higher percentage observed in the treatments with iron-ore $(\mathrm{F}=3.19, \mathrm{p}>0.05)$.

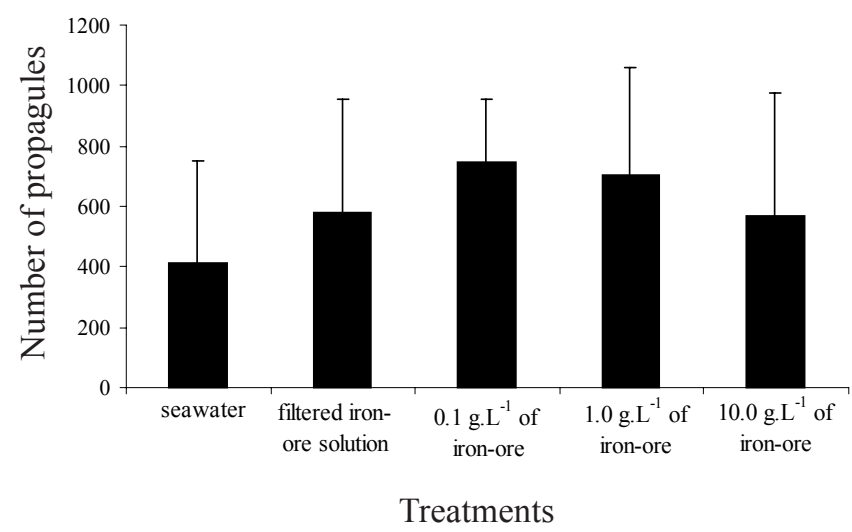

Figure 2. Number of propagules 48 hours after releasing. Bars indicate mean \pm standard deviation $(\mathrm{n}=9)$.

There was no significant difference $(\mathrm{F}=2.05$, $p>0.05$ ) between the percent survival rate of embryos of each treatment. The lower survival was observed in 10.0 g.L $\mathrm{L}^{-1}$ of iron $(68 \% \pm 20 \%)$ and 1.0 g.L $\mathrm{L}^{-1}(76 \% \pm 8 \%)$ treatments, whereas the highest ones were observed in the filtrated seawater $(84 \% \pm 8 \%)$ and 0.1 g. $\mathrm{L}^{-1}$ of iron-ore $(84 \% \pm 4 \%)$ treatments. An intermediate value was found for the 10.0 g. $\mathrm{L}^{-1}$ filtered iron-ore solution $(80 \% \pm 8 \%)$.

The zygotes fertilized in the presence of iron-ore were able to develop a variable number of filoids, arranged in a radial way after four weeks in culture (table 1). Only the young plants coming from the 10.0 g.L. L $^{-1}$ of iron medium did not develop in a radial way. Such plants also exhibited the shortest fronds $(3.9 \pm 0.7 \mathrm{~mm})$. There was a significant difference of the mean length of the fronds among treatments during the experiment $(\mathrm{p}<0.05)$.

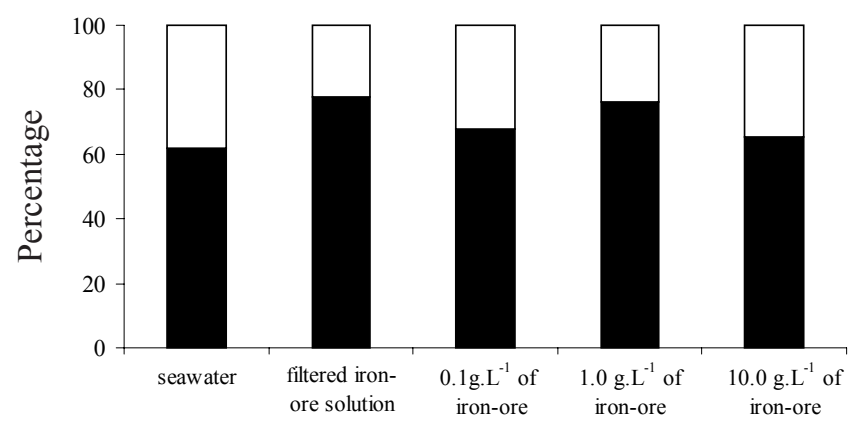

Treatments

Figure 3. Percentage of zygotes (dark box) and oocysts (light box) 48 hours after releasing. 
Table 1. Length of embryos $(\mathrm{mm})$ fertilized in the presence of iron-ore particles and grown in seawater enriched with Provasoli's solution for four weeks (mean \pm standard deviation, $\mathrm{n}=9$ ). $\mathrm{PES}=$ Provasoli's solution. Letters represent statistically similar values.

\begin{tabular}{|c|c|c|c|c|}
\hline \multirow[b]{2}{*}{ Treatment } & \multicolumn{4}{|c|}{ Time (weeks) } \\
\hline & 1 & 2 & 3 & 4 \\
\hline Seawater & $2.6 \pm 0.7 \mathrm{ab}$ & $3.5 \pm 0.4 \mathrm{ab}$ & $5.2 \pm 1.0 \mathrm{ab}$ & $6.3 \pm 0.9 \mathrm{bc}$ \\
\hline Filtered iron-ore solution & $2.6 \pm 0.9 \mathrm{ab}$ & $3.5 \pm 0.2 \mathrm{ab}$ & $4.8 \pm 0.9 \mathrm{ab}$ & $4.4 \pm 0.4 \mathrm{ac}$ \\
\hline 0.1 g. $\mathrm{L}^{-1}$ of iron-ore & $2.6 \pm 0.6 \mathrm{ab}$ & $3.6 \pm 0.5 \mathrm{ab}$ & $4.2 \pm 0.9 \quad \mathrm{a}$ & $6.1 \pm 0.8 \mathrm{bc}$ \\
\hline 1.0 g. $\mathrm{L}^{-1}$ of iron-ore & $3.2 \pm 0.7 \quad b$ & $4.1 \pm 0.9 \quad b$ & $5.9 \pm 0.9 \quad$ b & $7.0 \pm 0.9 \quad b$ \\
\hline 10.0 g. $\mathrm{L}^{-1}$ of iron-ore & $2.0 \pm 0.8 \quad \mathrm{a}$ & $2.8 \pm 0.9 \quad \mathrm{a}$ & $3.9 \pm 0.6 \quad \mathrm{a}$ & $3.9 \pm 0.7 \quad a$ \\
\hline ANOVA & $\mathrm{F}=2.73 *$ & $\mathrm{~F}=6.74 *$ & $\mathrm{~F}=4.96^{*}$ & $\mathrm{~F}=10.44^{*}$ \\
\hline
\end{tabular}

* significantly different

There was some growth in all treatments during the first week of the experiment (table 2). After four weeks the initial filoid could be seen, but they failed to expand $(\mathrm{F}=84.00, \mathrm{p}<0.05)$ in three concentrations of iron-ore without PES $\left(0.1,1.0\right.$ and 10.0 g. $\left.\mathrm{L}^{-1}\right)$. Maximum frond development was observed for the treatment with seawater + PES $(5.3 \pm 0.8 \mathrm{~mm})$. Plants in all PES-enriched treatments had a better development than those in not-enriched media (figure 4).

The plants kept in seawater + PES for a month died in the second week after being transferred to the 10.0 g.L.- $\mathrm{L}^{-1}$ of iron-ore solution (figure 5), whereas those transferred to the 10.0 g. $\mathrm{L}^{-1}$ of filtered iron solution stopped growing after the first week. The plants kept in PES continued to develop in this medium until the end of the experiment (four weeks).
Iron-ore strongly interfered with the sinking velocity of the zygotes. The zygotes in seawater $\left(6.5 \pm 2.1 \mathrm{~mm} . \mathrm{s}^{-}\right.$ $\left.{ }^{1}\right)$ and 10.0 g.L. ${ }^{-1}$ filtered iron-ore solution $(5.6 \pm 1.7$ $\left.\mathrm{mm} . \mathrm{s}^{-1}\right)$ sank more slowly than those from the $0.1(9.2$ $\left.\pm 2.5 \mathrm{~mm} . \mathrm{s}^{-1}\right), 1.0\left(23.0 \pm 4.7 \mathrm{~mm} \cdot \mathrm{s}^{-1}\right)$ and $10.0 \mathrm{~g} . \mathrm{L}^{-1}$ $\left(32.6 \pm 9.8 \mathrm{~mm} \cdot \mathrm{s}^{-1}\right)$ iron-ore solutions $(\mathrm{F}=28.2, \mathrm{p}<$ $0.05)$.

The P-I curves for $S$. vulgare showed an increase in photosynthesis with irradiance for both treatments (figure 6). Photoinhibition was not observed over one hour of incubation. The plants incubated with iron-ore showed slightly higher values for the maximum rate of photosynthesis at saturating irradiance $\left(\mathrm{P}_{\max }\right)$ and for the dark respiration than the control ones (table 3). However, differences were not statistically significant $(t=0.65, p>0.05)$. The initial slope of the P-I curve

Table 2. Length of embryos $(\mathrm{mm})$ fertilized in seawater and grown in the different treatments during four weeks (mean \pm standard deviation, $\mathrm{n}=10$ ). $\mathrm{PES}=$ Provasoli's solution. Letters represent statistically similar values.

\begin{tabular}{|c|c|c|c|c|}
\hline \multirow[b]{2}{*}{ Treatment } & \multicolumn{4}{|c|}{ Time (weeks) } \\
\hline & 1 & 2 & 3 & 4 \\
\hline Seawater & $0.8 \pm 0.4 \quad a$ & $1.0 \pm 0.2 \quad \mathrm{~d}$ & $1.0 \pm 0.1 \quad b$ & $1.7 \pm 0.2 \quad \mathrm{a}$ \\
\hline Seawater + PES & $2.6 \pm 0.1 \quad b$ & $3.4 \pm 0.5 \quad \mathrm{a}$ & $4.6 \pm 1.0 \quad \mathrm{a}$ & $5.3 \pm 0.8 \quad b$ \\
\hline Filtered iron-ore solution & $0.8 \pm 0.1 \quad \mathrm{~d}$ & $1.1 \pm 0.2 \quad \mathrm{~d}$ & $1.2 \pm 0.5 \quad b$ & $1.2 \pm 0.1 \quad \mathrm{a}$ \\
\hline Filtered iron-ore solution + PES & $1.2 \pm 0.2 \mathrm{ec}$ & $1.9 \pm 0.4 \mathrm{bc}$ & $2.6 \pm 0.6 \mathrm{de}$ & $3.7 \pm 1.0 \mathrm{~cd}$ \\
\hline $0.1 \mathrm{~g} . \mathrm{L}^{-1}$ of iron-ore & $0.9 \pm 0.1 \mathrm{dc}$ & $1.2 \pm 0.3 \quad b$ & $1.4 \pm 0.3 \mathrm{ce}$ & $1.3 \pm 0.3 \mathrm{bd}$ \\
\hline 0.1 g. $\mathrm{L}^{-1}$ of iron-ore + PES & $2.1 \pm 0.5 \quad \mathrm{a}$ & $2.5 \pm 0.7 \quad \mathrm{a}$ & $3.1 \pm 0.5 \mathrm{ac}$ & $4.5 \pm 0.6 \quad b$ \\
\hline 1.0 g. $\mathrm{L}^{-1}$ of iron-ore & $0.8 \pm 0.1 \quad \mathrm{~d}$ & $1.2 \pm 0.2 \mathrm{~cd}$ & $1.0 \pm 0.2 \mathrm{bd}$ & $1.5 \pm 0.4 \quad \mathrm{a}$ \\
\hline 1.0 g. $\mathrm{L}^{-1}$ of iron-ore + PES & $2.8 \pm 0.7 \quad b$ & $3.5 \pm 0.6 \quad b$ & $3.9 \pm 0.8 \quad \mathrm{e}$ & $4.7 \pm 0.8 \quad b$ \\
\hline 10.0 g. $\mathrm{L}^{-1}$ of iron-ore & $0.7 \pm 0.1 \mathrm{edc}$ & $1.4 \pm 0.3 \quad \mathrm{~d}$ & $1.6 \pm 0.3 \quad b$ & $1.4 \pm 0.3 \quad \mathrm{a}$ \\
\hline 10.0 g.L $\mathrm{L}^{-1}$ of iron-ore + PES & $0.8 \pm 0.2 \quad \mathrm{~d}$ & $2.3 \pm 0.6 \quad \mathrm{~d}$ & $3.2 \pm 0.6 \quad b$ & $4.7 \pm 1.0 \quad \mathrm{a}$ \\
\hline ANOVA & $\mathrm{F}=93.20 *$ & $\mathrm{~F}=98.20^{*}$ & $\mathrm{~F}=62.34^{*}$ & $\mathrm{~F}=84.02 *$ \\
\hline
\end{tabular}

* significantly different 
(alpha) was higher at the control curve and significant different from the iron-ore one $(t=2.30, p<0.05)$. The estimated value to the minimum light intensity to produce saturated photosynthesis $\left(\mathrm{I}_{\mathrm{k}}\right)$ was $106.26 \mu \mathrm{mol} . \mathrm{m}^{-2} . \mathrm{s}^{-1}$ to the control curve and $981.49 \mu \mathrm{mol} . \mathrm{m}^{-2} \cdot \mathrm{s}^{-1}$ to the iron-ore curve.

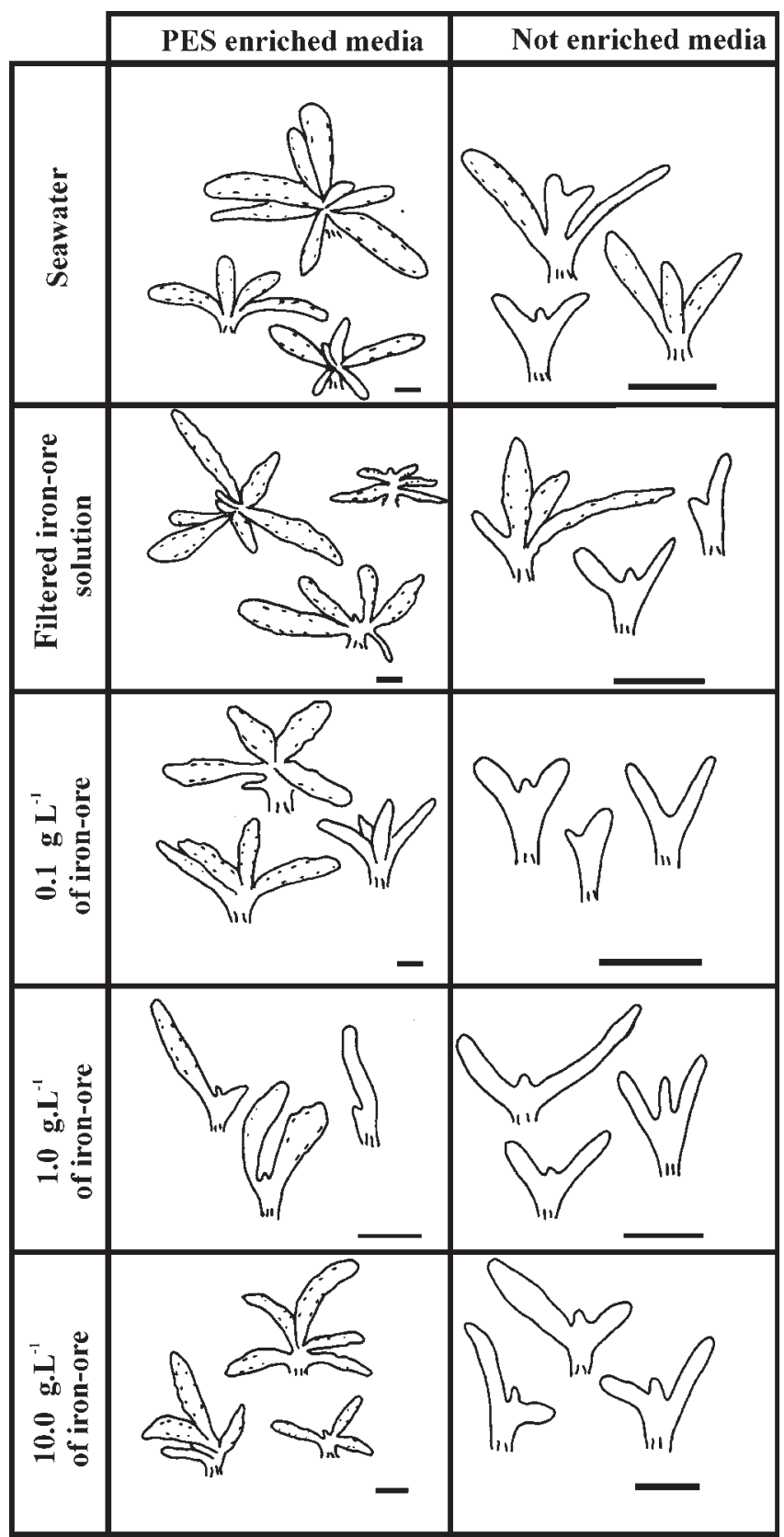

Figure 4. Morphological aspect of young plants cultivated after four weeks in the presence of iron-ore. Dots on some fronds represent cryptostomes. PES = Provasoli's solution. Scales indicate $1 \mathrm{~mm}$.

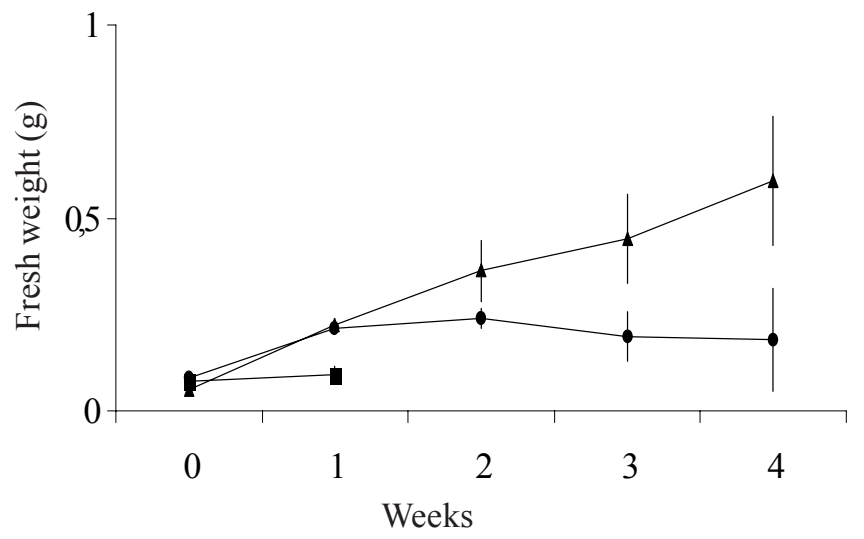

Figure 5. Fresh-weight (g) of young plants after one month of growth in seawater enriched with Provasoli's solution (PES) and transferred to different treatments. Bars indicate mean \pm standard deviation $(n=9)$. $\boldsymbol{\Delta}=$ seawater + PES; $\bullet=$ filtered iron-ore solution + PES and $\boldsymbol{\nabla}=10.0$ g.L $\mathrm{L}^{-1}$ of iron-ore + PES

\section{Discussion}

The high number of oocysts released in the iron-ore treatments indicated that the presence of the mineral did not prevent the passage of the female gametes through the ostiole. The oocysts of Sargassum vulgare are slowly released through the conceptacles ostiole and stay attached to it by a mucilaginous pedicel (Paula 1994). Closer observation of those structures showed that the particles are not able to penetrate them due to the paraphyses and the conceptacle's mucilage cover.

The fertilization of female gametes of $S$. vulgare was not prevented by the presence of iron-ore as zigotes were formed in all treatments. This result is different from the one found by Boney (1980) who observed a

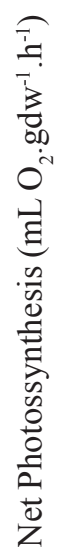
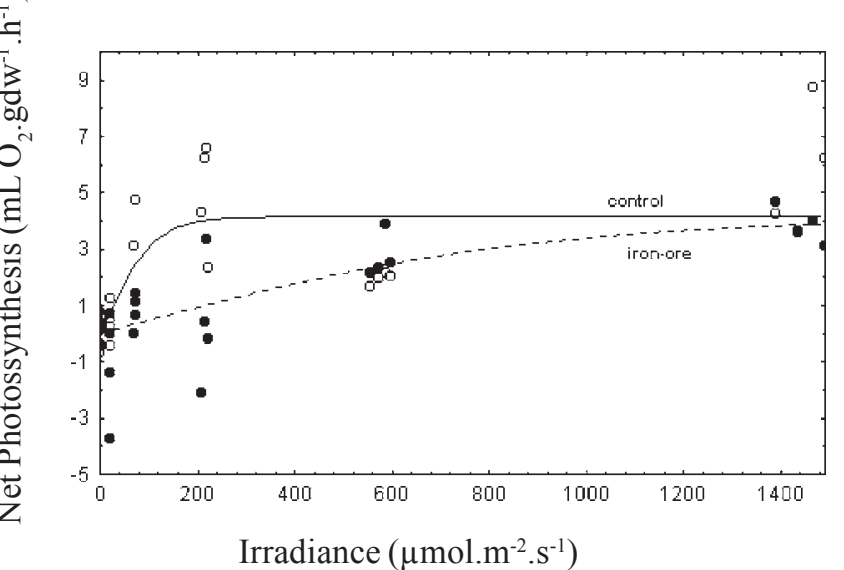

Figure 6: Photosynthesis-irradiance curves of $S$. vulgare in seawater (control - O) and in 10.0 g. $\mathrm{L}^{-1}$ iron-ore solution (O). 
Table 3. Comparision of means and standard-errors of estimated parameters derived from photosynthesis vs. irradiance (P-I) curves at $24.5^{\circ} \mathrm{C} . \mathrm{P}_{\max }=$ maximum photosynthetic rate at saturating irradiance; $\alpha=$ initial slope of the curve at pre-saturation irradiance; $\mathrm{R}=$ rate of respiration and $\mathrm{I}_{\mathrm{k}}=$ light saturation parameter.

\begin{tabular}{lccc}
\hline & Control curve & Iron-ore curve & Student's t test \\
\hline $\mathrm{P}_{\max }\left(\mathrm{mLO}_{2} \cdot \mathrm{gdw}^{-1} \cdot \mathrm{h}^{-1}\right)$ & $4.16 \pm 0.56$ & $4.19 \pm 1.23$ & $\mathrm{t}=0.02$ \\
$\alpha\left(\mathrm{mLO}_{2} \cdot \mathrm{gdw}^{-1} \cdot \mathrm{h}^{-1}\left(\mu \mathrm{mol} \cdot \mathrm{m}^{-2} \cdot \mathrm{s}^{-1}\right)^{-1}\right)$ & $0.039 \pm 0.015$ & $0.004 \pm 0.002$ & $\mathrm{t}=2.30 *$ \\
$\mathrm{R}\left(\mathrm{mLO}_{2} \cdot \mathrm{gdw}^{-1} \cdot \mathrm{h}^{-1}\right)$ & $0.131 \pm 0.48$ & $0.232 \pm 0.48$ & $\mathrm{t}=0.65$ \\
$\mathrm{I}_{\mathrm{k}}\left(\mu \mathrm{mol} \cdot \mathrm{m}^{-2} \cdot \mathrm{s}^{-1}\right)$ & 106.26 & 981.49 & - \\
\hline
\end{tabular}

* significantly different

reduction in the power of Fucus serratus L. oocysts laden with iron-ore to attract spermatozoids. He observed that this effect might be due to the adsorption of fucoserratene, a sperm attractant released by the oocysts, to the inorganic iron particles.

In the experiment where fecundation occurred in the presence of iron, the fronds showed a good growth except in 10.0 g.L. ${ }^{-1}$ of iron-ore solution. It was clear that the propagules were coated by iron during receptacles transfer to clean water. Norton (1978) stated that even a thin coat of silt may smother the attached germlings and thereby, prevent the attachment of settling propagules. The survival of the embryos was related to their ability to grow above the iron-ore layer during the first two weeks. After a fast initial enlargement, the germlings usually developed without problem. Those that did not grow seemed to remain viable for at least two weeks before degenerating in the higher iron concentration. Norton (1978) noticed that spores of Saccorhiza polyschides (Lightf.) Batt. and Laminaria saccharina (L.) Lamour. germinated and grew normally when they were able to settle on top of the sediment. However, even though they still germinated when covered by a silt layer, few gametophytes were produced and no sporophytes were formed.

The slow development of the young plants and the lower percent survival of embryos in treatments characterized by high iron-ore concentrations was certainly caused by the complete coating of the embryos during the first week of development and not by a toxic effect of any substance associated with the metal. This is confirmed by the young plants good growth in the 10.0 g.L. $\mathrm{L}^{-1}$ filtered iron-ore solution enriched with PES. In this case, the iron-ore effect may be similar to natural sediment in the environment. The same result was found by Hyslop \& Davies (1998), studying the effect of colliery waste over Ulva lactuca L. Increase in local sedimentation is one of the difficulties found by embryos during settlement, as they usually require bare rock to attach (Norton 1978, Schramm 1996). Siltation was pointed as one of the possible causes for the migration of Fucus vesiculosus L. to higher levels on the shore of Sweden, effectively changing the zonation pattern of the region (Eriksson et al.1998).

The presence of particulate matter on the surface of Sargassum plants is not necessarily harmful. Schaffelke (1999) found that particulate organic matter had a significantly positive effect on growth rates and on tissue nutrient content of S. linearifolium (Turner) C. Agardh. It seems reasonable to expect that different kinds of particulate matter would induce different kinds of response. Iron-ore is composed of dark particles and have no organic compounds attached to it.

Results showed that PES medium influenced the development of Sargassum. The use of treatments with and without Provasoli's medium was necessary to establish the eventual role of the ETDA (present at Provasoli's medium), in making iron available to the algae. The best observed growth was found in treatment with seawater enriched with PES. The embryos growth was limited by the absence of PES, whether or not iron was present.

The high sinking velocity of zygotes in the presence of iron-ore particles confirms the results found by Boney (1980) using oospheres of Fucus serratus L. Zygotes act like aggregation centers for the iron-ore, becoming coated with particles as soon as they are exposed to them. This could influence the location in rocky shores where germlings are going to settle and thus change the species distribution pattern. The sink velocities found for 10.0 g.L. $\mathrm{L}^{-1}$ iron-ore treatment $\left(32.6 \pm 9.89 \mathrm{~mm} \cdot \mathrm{s}^{-1}\right)$ was five times greater than on treatments where no iron-ore was added. Sargassum species are known to have relative fast sinking propagules (Kendrick \& Walker 1995). The propagules of Sargassum muticum (Yendo) Fensholt, with mean 
size of $155.8 \pm 3.38 \mu \mathrm{m}$ (mean $\pm \mathrm{SD})$, can sink with speeds of $0.53 \pm 0.01 \mathrm{~mm} . \mathrm{s}^{-1}$ (mean $\pm \mathrm{SD}$ ) (Deysher \& Norton 1982).

It seems logical to assume the faster the embryos sink, closer to the parent plant they will settle. Thus, embryos which are not coated with particles should be able to disperse over larger distances than their coated counterparts, thereby affecting the spatial distribution of adult plants within an algal bed. The effect of the canopy of adult Sargassum on recruit settlement and survival is a very debated subject in seaweed ecology (Paine 1990, Kendrick 1994, Stiger \& Payri 1999). Sargassum propagules seem to have a very short range of dispersal, settling within one meter of the parent plant in most cases (Kendrick \& Walker 1995, Stiger $\&$ Payri 1999). Young plants surviving under the canopy of adult plants (Paula 1994) may become the source for establishment or persistence of the beds when the canopy start to decay (Kimura et al. 1987).

The tendency to form aggregates due to particle attraction can also influence the settlement density of the germlings, leading to an intense competition for light and nutrients during the early phases of development. This intra-specific competition could result in growth reduction or even death (Creed et al. 1997). Still, a high concentration of propagules may be a positive factor for successful colonization, as the recruits would be close to their parents and to a suitable habitat (Kendrick \& Walker 1995).

The photosynthesis experiment showed that the iron-ore did not affect Sargassum maximum rate of photosynthesis $\left(\mathrm{P}_{\max }\right)$ in saturating irradiance. This parameter is related to variations in temperature, nutrients, pigment composition and species life history (Coutinho \& Zingmark 1987). As all these factors were similar in the experiments, it was reasonable not to find any large difference between the curves. Still, the efficiency of photosynthesis in low irradiance, measured by the initial slope of the P-I curve (alpha), was lower at the iron-ore curve, suggesting that there was not enough light reaching the fronds, probably because the iron-ore was coating the fronds, acting like another screening in the experiment. Coutinho \& Zingmark (1987) mentioned that alpha could be a more stable parameter than $\mathrm{P}_{\max }$ since, as a function of the photochemical reactions, it is primarily light dependent and therefore it is species and temperature independent. According to Koh \& Jo (1991), variation in the incident light intensity at any depth would be a function of solar radiation, water transparency as well as time, date and latitude. This could be aggravating in sites with high turbidity, natural or induced by effluents. The values for $\mathrm{I}_{\mathrm{K}}$ were nine times higher in the iron-ore presence $\left(891.49 \mu \mathrm{mol} . \mathrm{m}^{-2} \cdot \mathrm{s}^{-1}\right)$ than at the control (106.26 $\left.\mu \mathrm{mol} . \mathrm{m}^{-2} \cdot \mathrm{s}^{-1}\right)$ indicating that, at low irradiances, Sargassum plants need more light to reach saturation at contaminated sites, such as Camburi Beach. On the other hand, Paula (1994) found that young plants of S. cymosum were able to grow in a large range of irradiance $\left(9.2-184.0 \mu \mathrm{mol} . \mathrm{m}^{2} . \mathrm{s}^{-1}\right)$, temperature $\left(14-30{ }^{\circ} \mathrm{C}\right)$ and salinity (10-35 PSU).

The presence of iron-ore did not prevent the release and development of the propagules, but it does not mean, that the same would occur on a rocky shore. A fast sinking ability may be an advantage to the increase of a population an algal bed. However, if the iron-ore coated propagules are not able to develop rizoids in a very short period of time, they will easily be dislodged by water currents (Devinny \& Volse 1978).

The results found confirm the initial hypothesis that the iron-ore particles when in high concentration (10.0 g.L $\left.\mathrm{L}^{-1}\right)$ reduce the growth of Sargassum vulgare as they recovered the embryos, juveniles and young plants. The presence of the particles did not affect the net photosynthesis of adult plants, only the values of irradiance to achieve $\mathrm{P}_{\max }$. The hypothesis that the particles could difficult the release of gametes, percentage of zygotes formed and the percentage survival of the embryos were not confirmed. In future, more studies should be done in order to evaluate the ability of Sargassum and other species to retain ironore particles on their fronds.

Acknowledgements - The authors acknowledge the assistance given by Carmem Almada and Rafael Loureiro during the experiment. We also wish to thank Aline W.L. Rodrigues for her help with the English version of the manuscript and Minerações Brasileiras Reunidas for the iron-ore used in the experiments.

\section{References}

BONEY, A.D. 1978. Marine algae as collectors of iron ore dust. Marine Pollution Bulletin 9:175-180.

BONEY, A.D. 1980. Effects of seawater suspensions of iron ore dust on Fucus oospheres. Marine Pollution Bulletin 11:41-43.

BURRIDGE, T.R., KARISTIANOS, M. \& BIDWELL, J. 1999. The use of aquatic macrophyte ecotoxicological assays in monitoring coastal effluent discharges in Southern Australia. Marine Pollution Bulletin 39:89-96.

BURROWS, E.M. 1971. Assessment of pollution effects by the use of algae. Proceedings of the Royal Society of London B 177:295-306. 
COUTINHO, R. \& ZINGMARK, R. 1987. Diurnal photosynthetic responses to light by macroalgae. Journal of Phycology 23:336-343.

COUTINHO, R., CUNHA, V.F.G.V., SANTOS, S., PEREIRA, R.C., MARAUT, M.C.S. \& LAVRADO, H.P. 1989. Projeto Recrutamento. Variação espacial das curvas de fotossíntese vs. luz nas algas bentônicas da região de Arraial do Cabo e adjacências, RJ. Ínsula 19:169-178.

CREED, J.C., NORTON, T.A. \& KAIN, J.M.J. 1997. Intraspecific competition in Fucus serratus germling: The interaction of light, nutrients and density. Journal of Experimental Marine Biology and Ecology 212:211-223.

DE WREEDE, R.E. 1978. Growth in varying culture conditions of embryos of three Hawaiian species of Sargassum (Phaeophyta, Sargassaceae). Phycologia 17:23-31.

DEVINNY, J.S. \& VOLSE, L.A. 1978. Effects of sediments on the development of Macrocystis pyrifera gametophytes. Marine Biology 48:343-348.

DEYSHER, L. \& NORTON, T.A. 1982. Dispersal and colonization in Sargassum muticum (Yendo) Fensholt. Journal of Experimental Marine Biology and Ecology 56:179-195.

ERIKSSON, K., JOHANSSON, G. \& SNOEIJS, P. 1998. Long-term changes in the sublittoral zonation of brown algae in the southern Bothnian Sea. European Journal of Phycology 33:241-249.

HANISAK, M.D. \& SAMUEL, M.A. 1987. Growth rates in culture of several species of Sargassum from Florida, USA. Hydrobiologia 151/152:399-404.

HOPKIN, R. \& KAIN, J.M. 1978. The effects of some pollutants on the survival, growth and respiration of Laminaria hyperborea. Estuarine and Coastal Marine Science 7:531-553.

HYSLOP, B.T. \& DAVIES, M.S. 1998. Evidence for abrasion and enhanced growth of Ulva lactuca $\mathrm{L}$. in the presence of colliery waste particles. Environmental Pollution 101:117-121.

JASSBY, A.D. \& PLATT, T. 1976. Mathematical formulation of the relationship between photosynthesis and light for phytoplankton. Limnology and Oceanography 21:540-547.

KENDRICK, G.A. 1994. Effects of propagule settlement density and adult canopy on survival of recruits of Sargassum spp. (Sargassaceae:Phaeophyta). Marine Ecology Progress Series 103:129-140.

KENDRICK, G.A. \& WALKER, D.I. 1995. Dispersal of propagules of Sargassum spp. (Sargassaceae: Phaeophyta): Observations of local patterns of dispersal and consequences for recruitment and population structure. Journal of Experimental Marine Biology and Ecology 192:273-288.
KIMURA, T., OROSCO, C.A. \& OHNO, M. 1987. Ecological study of Sargassum okamurae Yoshida et T. Konno in Tosa Bay, Japan. Reports of the USA Marine Biological Institute of Kochi University 9:149-167.

KOH, C.H. \& JO, S.O. 1991. An estimation of the algal production of Sargassum confusum (Phaeophyta) on the Coast of Ohori, East Sea, Korea, by mathematical models based on photosynthetic rates and biomass changes. Journal of the Oceanographic Society of Korea 26:108-116.

MANSILLA, O.A. \& PEREIRA, S.M.B. 1998. Variação temporal da abundância e composição específica da macroflora associada a uma população de Sargassum (Fucophyceae) do litoral sul de Pernambuco, Brasil. Boletim de Botânica, Universidade de São Paulo 17:271-276.

MITCHELL, G.J.P., NASSAR, C.A.G., MAURAT, M.C.S. \& FALCÃO, C. 1990. Tipos de vegetação marinha da Baía do Espírito Santo sob a influência da poluição Espírito Santo (Brasil). In Anais do II Simpósio de Ecossistemas da Costa Sul e Sudeste Brasileira Estrutura, Função e Manejo. (S. Watanabe, coord.) Aciesp, São Paulo, v.1, p.202-214.

NORTON, T.A. 1977. The growth and development of Sargassum muticum (Yendo) Fensholt. Journal of Experimental Marine Biology and Ecology 26:41-53.

NORTON, T.A. 1978. The factors influencing the distribution of Saccorhiza polyschides in the region of Lough Ine. Journal of the Marine Biological Association of the United Kingdom 58:527-536.

PAINE, R.T. 1990. Benthic macroalgal competition: complications and consequences. Journal of Phycology 26:12-17.

PAULA, E.J. 1988. O gênero Sargassum C. Ag. (Phaeophyta - Fucales) no litoral do Estado de São Paulo, Brasil. Boletim de Botânica, Universidade de São Paulo 10:65-118.

PAULA, E.J. 1994. Influência da temperatura, luz e salinidade no crescimento de plântulas de Sargassum cymosum C. Agardh var. cymosum (Phaeophyta, Fucales). Revista Brasileira de Botânica 17:53-60.

PAULA, E.J. \& OLIVEIRA FILHO, E.C. 1980. Aspectos fenológicos de duas populações de Sargassum cymosum (Phaeophyta - Fucales) do litoral de São Paulo, Brasil. Boletim de Botânica, Universidade de São Paulo 8:21-39.

PROVASOLI, L. 1968. Media and prospects for cultivation of marine algae. In Cultures and collections of algae (A. Watanabe \& A. Hatori, eds.). Japanese Society of Plant Physiology, Hakone, p.63-75.

SCHAFFELKE, B. 1999. Particulate organic matter as an alternative nutrient source for tropical Sargassum species (Fucales, Phaeophyceae). Journal of Phycology 35:1150-1157. 
SCHRAMM, W. 1996. The Baltic Sea and its transition zones. In Marine benthic vegetation - recent changes and the effects of eutrophication. (W. Schramm \& P.H. Nienhuis, eds.) Ecological Studies 123:131-163.

STIGER, V. \& PAYRI, C.E. 1999. Spatial and temporal patterns of settlement of the brown macroalgae Turbinaria ornata and Sargassum mangarevense in a coral reef on Tahiti. Marine Ecology Progress Series 191:91-100.
SUNDA, W.G. \& HUNTSMAN, S.A. 1995. Iron uptake and growth limitation in oceanic and coastal phytoplankton. Marine Chemistry 50:189-206.

SZÉCHY, M.T.M. \& PAULA, E.J. 2000. Padrões estruturais quantitativos de bancos de Sargassum (Phaeophyta, Fucales) do litoral dos estados do Rio de Janeiro e São Paulo, Brasil. Revista Brasileira de Botânica 23:121-132.

WISEMAN, D.R. 1976. Observations of the vegetative morphology of the red algal genus Ochtodes J. Agardh (Rhizophyllidaceae, Gigartinales). Phycologia 15:143-147. 